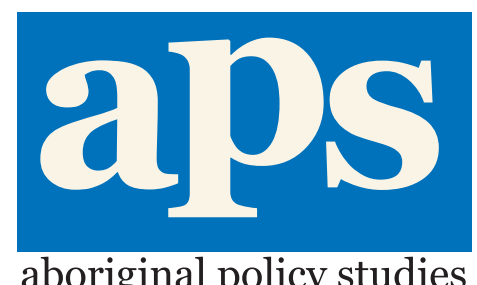

\title{
Article
}

\section{The United Nations Declaration on the Rights of Indigenous Peoples and Urban Aboriginal Self- Determination in Canada: A Preliminary Assessment}

\author{
Yale D. Belanger \\ aboriginal policy studies, Vol. 1, no. 1, 2011, pp. 132-161 \\ This article can be found at: \\ http://ejournals.library.ualberta.ca/index.php/aps/1/1/Belanger.pdf
}

ISSN: 1923-3299

aboriginal policy studies is an online, peer-reviewed and multidisciplinary journal that publishes original, scholarly, and policy-relevant research on issues relevant to Métis, non-status Indians and urban Aboriginal people in Canada. For more information, please contact us at apsjournal@ualberta.ca or visit our website at

www.ualberta.ca/NATIVESTUDIES/aps/

or

http://ejournals.library.ualberta.ca/index.php/aps/ 


\title{
The United Nations Declaration on the Rights of Indigenous Peoples and Urban Aboriginal Self-Determination in Canada: A Preliminary Assessment
}

\author{
Yale D. Belanger ${ }^{1}$ \\ University of Lethbridge
}

\begin{abstract}
The United Nations Declaration on the Rights of Indigenous Peoples (2007) implicitly recognizes urban Indigenous self-determination and acknowledges collective and individual Indigenous rights. This essay examines the tensions associated with the Declaration's acknowledged Indigenous individual choice to determine political affiliation with its recognition of Indigenous collective self-determination. The purpose is to expose the complexities inherent when attempting to reconcile the Declaration with First Nations and urban Aboriginal political aspirations, Canadian court decisions, federal Indian policies, and the protective mechanisms of the Canadian Charter of Rights and Freedoms. The author cautions that additional studies are required probing these and other issues prior to First Nation, Aboriginal, and Canadian political leaders venturing forward in their desires to implement and activate the Declaration's provisions to promote Indigenous community development.
\end{abstract}

\section{Introduction}

After several years' contentious debate, Canada formally endorsed the United Nations Declaration on the Rights of Indigenous Peoples on 12 November 2010. ${ }^{2}$ Aboriginal support for the Declaration-specifically for its provisions aimed at augmenting First Nations and urban Aboriginal selfdetermination-was widespread. We do not yet fully understand how the Declaration will come to influence Aboriginal-Canadian relations, nor do we know how it could potentially benefit urban Aboriginal peoples. Aboriginal aboriginal policy studies, Vol. 1, no. 1, 2011

ISSN: 1923-3299

www.ualberta.ca/NATIVESTUDIES/aps/ 
support, however, suggests we can anticipate that both First Nations and urban Aboriginal communities will challenge one another for political legitimacy, economic constancy, and social stability as they simultaneously advocate for government adherence to the Declaration's spirit and intent. Accordingly, this paper is an evaluation of the novel and imposing set of challenges that will result when urban Aboriginal communities utilize the Declaration's provisions to help extend their political reach.

Several salient issues inform this analysis. First, a close reading of several of the Declaration's articles (1, 2, 3, 4, 5, 6, 9, 33, and 35) exposes competing definitions of First Nations and urban Aboriginal selfdetermination. Second, the Declaration's focus on communal rights also appears to challenge the individual rights protections in the Charter of Rights and Freedoms, while its individual rights discourse challenges a federal Indian policy focus on communal Aboriginal rights. Finally, a set of Supreme and Federal Court decisions (1999-2007) concluding that urban Aboriginal communities are political communities akin to First Nations complicates relations between urban Aboriginals and First Nations and has the potential to challenge community development strategies (Belanger 2010). In this preliminary inquiry into the potential effects of the UN declaration, I have three primary goals: (1) to identify and evaluate the emergent tensions confronting the community development strategies of urban Aboriginal leaders; (2) to determine whether reconciling these distinctive interpretations to the benefit of urban Aboriginal political development is indeed possible; and (3) by identifying these complexities, to warn those considering utilizing the Declaration as a mechanism for improving self-determination of the associated issues and of the Declaration's potentially destabilizing effects.

\section{Background}

On 13 September 2007, a quarter century after it was proposed, the United Nations General Assembly overwhelmingly passed the United Nations Declaration on the Rights of Indigenous Peoples by a vote of 144 to 4 (with 11 abstentions). ${ }^{3}$ Cited as the Indigenous equivalent to the United Nations Declaration on Human Rights (1948), the Declaration establishes the essential standards for the recognition and protection of the world's 370 million Indigenous peoples' inherent rights. Initially, Canada was one of four countries that refused to ratify the Declaration on the basis that it was irreconcilable with its constitutional foundation and ultimately a threat to 
non-Native rights. The Canadian minister of Indian and Northern Affairs Canada, Chuck Strahl, branded articles 19 and 26 particularly problematic. ${ }^{4}$ Lamenting that the "situation of indigenous peoples around the world warrants concerted and concrete international action," he criticized the international political community's acceptance of what he identified as "a declaration that falls short of what is required to truly address the interests of Indigenous peoples around the world" (Strahl 2007). Responding to domestic calls for its acceptance, the Conservative government announced during the 2010 Throne Speech that Canada would re-consider supporting the Declaration. This occurred following endorsements by Australia, New Zealand, Colombia, and Samoa, and a pledge by the United States to reassess its opposition. Canada was, by then, proudly portraying itself domestically and internationally as "a country with an Aboriginal heritage," dedicated to taking the needed "steps to endorse this aspirational document in a manner fully consistent with Canada's Constitution and laws." Eight months later, Canada endorsed the Declaration. The next step now is to generate consensus concerning the Declaration's domestic meaning, as First Nations, Aboriginal and Canadian politicians work toward its implementation.

As a guide to developing modern Indigenous policies, however, the Declaration remains untested in North America. As Chairperson of the Permanent Forum on Indigenous Issues, Victoria Tauli-Corpuz, suggests, several questions remain unanswered.

When you talk about the right to lands, territories and resources, what does that mean in concrete terms? Does this mean ancestral land mapping or delineation? Does this mean changing the laws of the land to conform to respecting and promoting that right? In terms of health, how can we integrate traditional healing systems and how are they considered in the health delivery systems of countries? ${ }^{5}$

These important issues demand clarification, as does the UN's acceptance of urban Aboriginal people's self-determining status. The Declaration does not differentiate between urban and rural Indigenous populations, indicating that urban Aboriginal peoples are now acknowledged as self-determining political communities. Also, consideration needs to be made of the Declaration's potential impact upon the evolution of urban Aboriginal self-determination: how it will influence Canada's 
relationship with the urban Aboriginal community? How First Nation-urban Aboriginal relations will be influenced? Significantly, the Declaration's tabling corresponded with a period in which the Canadian courts were ruminating similar questions. The Federal Court of Canada's Misquadis (2002) decision, for example, recognized urban Aboriginal communities as political communities analogous to First Nations, a conclusion that resonates with the UN's acknowledgment of urban Aboriginal self-determination status. ${ }^{6}$ Misquadis offers progressive insights that influence our general understanding of what the inherent right to self-government means in an urban Aboriginal setting. A deeper reading suggests further that, while beneficial to First Nations, the Declaration will aid urban Aboriginal leaders pursuing amplified self-determining status.

Conferring self-determining status is an important action that is also fraught with significant risks. The Declaration, for one, does not speak to nor does it account for existing variants of domestic Aboriginal self-government and/or self-determination. It fails to reflect upon how colonialism influenced Indigenous political beliefs and ideologies, or how these changes have influenced contemporary political responses (see, e.g., Taiaike and Corntassel 2005). Canada's Indigenous peoples, as a result, are forced to maneuver in a complex political environment that, simultaneously, embraces Indian wardship and the inherent Aboriginal right to self-government along with a history of treaty relationships suggesting nation-to-nation relationships exist. Complicating this situation further is the urban Aboriginal community's fluorescence and the corresponding albeit unanswered questions surrounding their self-determining status and demands for federal and First Nations resources. ${ }^{7}$ With all of these forces now at play, what kind of impact will the Declaration's ratification have upon urban Aboriginal peoples and First Nations (and other) communities with competing political and economic interests (e.g., provincial governments)?

\section{Creating the Declaration}

The Declaration is a non-binding document that establishes the essential standards for the recognition and protection of international Indigenous peoples' rights, while offering policy makers and Indigenous people from around the world a framework to help mitigate socio-economic disadvantages (see United Nations Permanent Forum on Indigenous Issues 2007). More than twenty years in the making (1984-2004, followed 
by three years of ratification dialogues), the Declaration is the result of Indigenous demands, dating back to the 1960s, for the formal recognition of their rights. International recognition of Indigenous peoples' rights is a relatively recent trend that can be traced back to the International Labour Organization's (ILO) Convention No. 107 and Recommendation No. 104. Passed in 1957 and implemented in 1959, these two documents represent the first international juridical instruments addressing Indigenous peoples and their rights (see Rodrigues-Pinero 2005). A range of covenants followed that were intended to mitigate racial discrimination, including the UN's Committee on the Elimination of Racial Discrimination (1962), the International Convention on the Elimination of All Forms of Racial Discrimination (1965), and the International Covenant on Civil and Political Rights (1966). Indigenous peoples were rarely mentioned in these dialogues, however. In the wake of international decolonization trends and the US Civil Rights movement, Indigenous peoples began to more forcefully demand international recognition of their inherent rights by the late 1960s (GarciaAlix and Hitchcock 2009, 100). Several international and human rights organizations entered the debate, portraying Indigenous peoples as ethnic minorities entitled to protection against discrimination (Wilmer 1993). The efforts of individuals such as Canadian First Nation leader George Manuel (Shuswap), who helped organize a gathering of fifty-two international Indigenous leaders and two hundred observers at the Tseshaht First Nation on Vancouver Island in October 1975, further catalyzed Indigenous leaders to create the prominent World Council of Indigenous Peoples (McFarlane 1993).

The UN responded and made significant strides in its study of Indigenous issues. In 1971, for example, the UN Sub-commission on the Prevention of Discrimination and Protection of Minorities authorized a study entitled "The Problem of Discrimination Against Indigenous Populations," which remained unpublished until 1987 (see Martinez Cabo 1987). The Working Group on Indigenous Populations (WGIP) was endorsed in May 1982 and tasked with revising ILO Convention No. 107 to better reflect Indigenous diversity. The convention was eventually passed in 1989, but many Indigenous groups proclaimed the new Convention's protective mechanisms inadequate against oppressive regimes. They also charged that the document lacked the leverage needed to secure Indigenous territorial repatriation. The WGIP, working with Indigenous representatives, responded to these and similar complaints. In 1993, it tabled a draft UN 
Declaration on the Rights of Indigenous Peoples, the same year the UN General Assembly proclaimed the International Decade of the World's Indigenous Peoples (1995-2004). Intended to raise awareness of and promote Indigenous peoples' rights, debates arose concerning the Declaration's pith and substance (see, e.g., Barsh 1996). After several years of negotiations, the General Assembly formally adopted the Declaration in 2007, conceding "the occurrence of a wide range of violations against indigenous peoples" while laying "out minimum standards for ensuring dignity, well-being, and physical and cultural survival" (Garcia-Alix and Hitchcock 2009, 103). Close observers were not surprised at Canada's negative response. Russel Barsh in particular concluded earlier that Canada's reputation as "the principle champion of indigenous peoples at the UN" was waning (1995, 107). Indigenous self-determination or, more specifically, its meaning, was a key point of contention, and an issue that Canadian officials refused to discuss.

\section{Aboriginal Self-Government and Self-Determination}

Self-determination has historically been associated with the right of a people to determine its own political destiny (see, e.g., Anaya 1996). In this milieu, Indigenous leaders have sought to foster development strategies that promote self-determination, cultural preservation, identity, and spirituality. As articulated recently in a UN document, "Human development is the community's well-being, articulating natural, environmental and social organizational values with rights. It is the possibility of maintaining a balance between these elements" (United Nations Permanent Forum on Indigenous Issues 2007). Sakej Henderson describes self-determination as a prerequisite "for the exercise of spiritual, territorial, social, cultural, economic, and political rights, as well as for practical survival" (2008a, 71). However, historically conflicting definitions, combined with a lack of legal certainty, make it difficult to determine specifically what groups could legitimately claim this right of self-determination (Anaya 1996). The concept of self-determination itself has undergone significant alterations in recent decades, expanding its scope to consider human beings and their role as individuals "engaged in the constitution and functioning of communities" (Anaya 1996, 77). As James Anaya illustrates, "Self-determination is not separate from other human rights norms; rather, self-determination is a configurative principle or framework complemented by the more specific 
human rights norms that in their totality enjoin the governing institutional order" $(1996,77)$.

Notably, self-determination as an internationally acknowledged right is not restricted to remote or rural areas, but this has not stopped Canadian politicians and academics from conflating Indigenous desires for self-determination with separation from the state. Interestingly, Aboriginal peoples in Canada have not historically promoted or advocated physical or ideological isolation. Rather, they have envisioned self-determination as a right to fulfill political desires that promote formal partnerships with nonAboriginal peoples and governments; an orientation that is guided by the spirit of historic and contemporary treaty relationships, continuing group rights, and existing constitutional arrangements (Henderson 2006; Macklem 2001).

Canada has embraced a divergent strategy for dealing with Aboriginal self-determination claims, relying on a federally sanctioned self-government model dependent upon federal recognition of Aboriginal self-government, rather than on the unequivocal recognition of its inherency. Fashioned in the 1980s, this approach situates Canadian officials in the enviable position of administering a self-government agenda that has remained largely unchanged for three decades (Belanger and Newhouse 2008). Somewhat paradoxically, Canada acknowledges the inherent Aboriginal right to selfgovernment in its Inherent Rights Policy (Canada 1995), which indicates that in matters "internal to their communities, integral to their unique cultures, identities, traditions, languages and institutions and with respect to their special relationship to their land and their resources," self-government rights are inherent and contained in S. 35 of the Constitution Act. ${ }^{8}$ This so-called "empty box" was expected to gradually fill with every court decision concerning Aboriginal rights, leading to a comprehensive set of criteria that were to develop organically and inform politicians as to what precisely self-government meant. ${ }^{9}$ Little has come of this approach, and the self-government ideal has become increasingly convoluted in recent years (Belanger and Newhouse 2008).

\section{Canada's International Acceptance of Indigenous Self-Determination}

Its limited domestic approach to Aboriginal self-government notwithstanding, Canada has signed various UN declarations acknowledging assorted forms of Indigenous self-determination while adhering to assorted mechanisms 
designed to assist federal officials to protect and ensure Indigenous rights (Henderson 2008a, 30). Accordingly, Canada's unwillingness to initially acknowledge the Declaration's criteria is incongruous with its past actions, particularly when one considers Canada's prior acceptance of the UN as an arbiter informing newly emerging international norms related to sovereignty and self-determination. Henderson, for one, concluded that Canada's reluctance to endorse the Declaration by no means negated the country's previous acceptance of Indigenous rights as symbolized by its participation in formulating and implementing various international agreements. Furthermore, despite minimal domestic support, the Declaration nevertheless crystallized the rights of Canada's Indigenous peoples in international law, which, according to Henderson's analysis, "have moved from a normative status to a 'hardened norm,' a legal regime” (Henderson 2008a, 51).

To summarize the relevant Declaration articles related to community and individual rights (i.e., 1, 2, 3, 4, 5, 6, 9, 33, 35): Indigenous peoples have the right to the full enjoyment, as a collective or as individuals, of all human rights and fundamental freedoms recognized in the Charter of the United Nations, the Universal Declaration of Human Rights, and international human rights law. ${ }^{10}$ Both as collectives and individuals, Indigenous peoples are considered free and equal to all other peoples and individuals, with rights to be free from any kind of discrimination, in the exercise of their rights, especially those based on their Indigenous origin or identity. ${ }^{11}$ Furthermore, they have the right of self-determination, and by virtue of that right they may freely determine their political status and freely pursue their economic, social, and cultural development. ${ }^{12}$ In exercising their right to self-determination, Indigenous peoples also have the right to autonomy or self-government in matters relating to their internal and local affairs, as well as ways and means for financing their autonomous functions..$^{13}$ Indigenous peoples and individuals have the right to maintain and strengthen their distinct political, legal, economic, social, and cultural institutions, while retaining their rights to participate fully, if they so choose, in the political, economic, social, and cultural life of the State. ${ }^{14}$ Additionally, every Indigenous individual has the right to a nationality. ${ }^{15}$ Indigenous peoples and individuals have the right to belong to an Indigenous community or nation, in accordance with the traditions and customs of the community or nation concerned. Discrimination arising from the exercise of such rights is impermissible. ${ }^{16}$ Indigenous peoples have the right to determine their own identity or membership in accordance with their customs and traditions. 
This does not impair the right of Indigenous individuals to obtain citizenship of the states in which they live. They also have the right to determine the structures and to select the membership of their institutions in accordance with their own procedures. ${ }^{17}$ Indigenous peoples have the right to determine the responsibilities of individuals to their communities. ${ }^{18}$

\section{Urban Aboriginal Peoples as Policy Artifacts}

The Declaration may acknowledge the self-determining status of urban Aboriginal peoples, but these peoples remain a unique Indigenous grouping in Canada that lacks official policy status. Despite growing urbanization, Aboriginal people are still considered foreign visitors occupying an alien environment, an incommensurability that obliges limited municipal, provincial, or federal concern (Peters 1996). Cities in this instance are colonial environments that perpetuate binaries identifying insider/outsider and citizen/other (Furniss 1999; see also Fiske, Belanger, and Gregory 2010), leading most Canadians to internalize the belief that urban Aboriginal peoples are displaced cultural curiosities (Francis 1992). A Canadian Indian policy designed to compel Indians to transition into being Canadian citizens reflects similar attitudes. ${ }^{19}$ Initially intended to facilitate Aboriginal transition into farming and ranching, the policy encouraged those who were unable to adapt to farming or ranching to relocate to nearby towns and cities. Unfortunately, policy did not allow for Aboriginal people to be both urban and reserve residents, as individuals were seen to be abandoning their heritage by moving to the city and obviously no longer needing the reserve (Borrows 2000). Over time, federal officials concluded that urban emigration assumed an individual's compliant acceptance of Canadian norms, and those who were seen as resisting urban relocation and remained on reserve became subject to increasingly aggressive attempts to compel their assimilation. Those who remained on reserves, however, retained legal status and, thus, federal attention and funding.

This poorly developed Indian bureaucracy and its attendant policies proved unsuccessful in several regards, not least of which was their failure to provide urban émigrés with the necessary resources to ease their urban transition and so promote their permanency in urban settings. Urban Aboriginal peoples utilized historic governing and social ideologies to devise new political and social models. ${ }^{20}$ Despite this remarkable adjustment, federal and provincial policies portray urban Aboriginal populations as a 
homogeneous grouping and heterogeneous cultural jumble of reserve expatriots who had willingly abandoned their communal environment for individual urban residency, a policy orientation that permits both federal and provincial officials to refuse responsibility for urban Aboriginal peoples. Beginning in the 1980s, urban Aboriginal leaders have attempted to counter these myths but their concerns have, at times, fallen on deaf ears despite the evolution of permanent populations. They continue to reach out to First Nations and federal leaders (and, increasingly, to provincial and municipal officials) in an effort to maintain and foster new political partnerships. ${ }^{21}$ Nevertheless, the federal policy model constructs urban Aboriginal peoples as being individuals who have abdicated their Indian status and, as a consequence, any and all claims to Aboriginal rights.

\section{The Canadian Courts and Urban Aboriginal Self-Determination}

The Supreme and Federal Courts of Canada have indicated in a recent set of decisions that the federal government's aforementioned policy of urban Aboriginal exclusion is not longer tolerable. Each court has argued that the process of "Aboriginality-residence" has the potential to discriminate against off-reserve residents. Beginning with Corbiere in 1999, the Supreme Court ruled that First Nations members living off-reserve were entitled to vote in band elections (Corbiere v. Canada, 221). The court determined that the Indian Act's voting provisions violated section 15(1) of the Canadian Charter of Rights and Freedoms, and so rendered them invalid. In the court's opinion, "Aboriginality-residence" was an analogous ground of discrimination, since the decision to live off-reserve was frequently compelled rather than voluntary, which led to numerous negative policy outcomes. Justices McLachlan and Bastrache concluded that "the complete denial to off-reserve members of the right to vote and participate in band governance treats them as less worthy and entitled, not on the merits of their situation, but simply because they live off-reserve" (Corbiere v. Canada, 221). They also stated that the distinction between reserve and off-reserve members for the purposes of voting presumed those individuals living offreserve were "persons who have chosen to be assimilated by the mainstream society" (224). Madame Justice L'Huereux-Dube noted this tension and concluded that, traditionally, "people have often been only seen as "truly Aboriginal' if they live on reserves" (258). 
In 2002, the Federal Court ruled that Human Resources and Skills Development Canada had discriminated against the urban Aboriginal community by failing to fund the infrastructure required for urban service delivery and to establish representative governance. Urban Aboriginal political organizations could represent urban Aboriginal interests, the court argued, suggesting further that off-reserve Aboriginal people were a group of self-organized, self-determining, and distinctive communities, analogous to a reserve community (Canada v. Misquadis 2002). The Esquega (2007) decision added to this nascent dialogue by ruling that reserve residence was not required for band councilors. Several key changes would emerge from these decisions, including: (1) the First Nations franchise was extended to band members living in cities, as were potentially the corresponding First Nations political obligations for urban band members; (2) the urban Aboriginal community was for the first time formally recognized a political community; and (3) outside funding was needed to aid urban Aboriginal development.

Each case challenged the popular belief that First Nations band members moving to cities were abandoning their home community and local political issues. The litigants in Esquega sought to run for office without being handicapped by residency requirements while retaining their franchise and, by extention, their First Nations citizenship. Perhaps of greatest importance, the Federal Court in Misquadis (2002) debunked the notion that urban Aboriginal peoples lack legitimacy and accountability. This case is significant for both off-reserve and non-status Indians as it provides legal recognition of Aboriginal communities "outside the constructs of bands and reserves under the Indian Act [while affirming] the rights of individuals in these communities to be given equal respect and consideration in application of the law" (Jamal 2005, 130). It also highlights how the courts, the federal government, and First Nations are interpreting these complex issues. The courts' insinuation into the self-determination discussion is notable, and the courts have, in the process, arguably become agents of Aboriginal self-determination. Nevertheless, they have granted urban Aboriginal communities a political status previously unacknowledged by the federal government.

As demonstrated above, urban Aboriginal peoples are progressing from unknown and forgotten communities to self-determining peoples. Canada's acceptance of earlier international covenants recognizing and protecting the rights of Indigenous peoples resonates with decisions by the 
Supreme and Federal Courts of Canada acknowledging urban Aboriginal peoples as political communities analogous to a First Nation (i.e., reserve communities). The UN Declaration's aversion to distinguishing between urban Aboriginal people and First Nations also suggests that urban Aboriginals may now claim self-determining rights during implementation negotiations to resolve the Declaration's domestic pith and substance. The convergence of these various perspectives means that urban Aboriginal peoples now are able to access international protective mechanisms to augment their self-governing authority, which offers unique opportunities to improve self-determination. Space limitations make an overall examination of the overarching complexity of the associated subject matter impossible; therefore, the final two sections of this paper will focus on how the Declaration, in concert with existing jurisprudence, informs ideas of Aboriginal self-determination. The focus will also be on how the inclusion of individual Indigenous rights will inform urban Aboriginal officials seeking to develop and expand upon new and existing governing models, while inevitably drawing neighbouring First Nations into the debate. Due to the self-determination's inherent complexities, I will focus on community citizenship norms.

\section{Individual Versus Collective Indigenous Rights}

Perhaps the most significant aspect of the Declaration is its confirmation of Indigenous collective and individual rights in articles 1, 2, 6, 7, 8, 9, 14, 17, $24,33,35,40$, and 44 . This is not at variance with Canada's conceptualization of individual and collective rights: collective rights have been acknowledged for Aboriginal, Anglophone, and Francophone communities. The courts have also framed Aboriginal rights as collective rights, whereas Aboriginal individuals have individual rights protections under the Charter of Rights and Freedoms. Prior to 1999, however, a group of Aboriginal individuals living off-reserve were not considered as possessing collective Aboriginal rights. As discussed above, the federal government currently does not recognize urban Aboriginal collective rights even if the courts have indicated the government's need to alter its position. Considering the measured pace of academic study and legal outcomes related to the nature of Aboriginal rights in Canada, the Declaration provides analysts with a progressive framework to interrogate the issues. But what exactly is the Declaration's message about individual Indigenous rights? And how does this message resonate 
with urban Aboriginal residents, who generally remain ignored as policy concerns by federal officials?

To help unravel the complexity introduced by the Declaration, a basic scenario will help us identify a number of complex policy concerns for consideration.

\section{A band member living in a city seeks to preserve political and social ties with their home First Nation by retaining their First Nation membership.}

This simple scenario is played out daily in Canada, as urban Aboriginal people/ First Nation members seek access to community resources unobtainable through government channels. Prior to engaging in an extended analysis, there are several important points to reflect upon. First, any analysis is informed by international norms respecting state sovereignty. Considered an essential attribute, all sovereign states "should possess jurisdiction over all persons and things within its territorial limits and in all causes civil and criminal arising within these limits" (Starke 1989, 202). Consequently, an independent, authoritative state is considered immune from the intrusions of outside powers, a gambit governing officials have strategically employed to undermine UN directives. Second, the Declaration's architects have homogenized the world's varied Indigenous peoples and cultures by placing them into the all-inclusive category of "Indigenous Peoples." This is an important development for, according to Article 1 of the Declaration, urban Aboriginal people are now acknowledged as self-determining, political communities.

Third, the existing Indian policy environment in Canada perpetuates this political disjuncture. Historically, Canadian officials refused to acknowledge hereditary leadership selection processes and membership selection models, choosing instead to implement the Gradual Civilization Act (1869), followed by the Indian Act (1876), to systematically dismantle these traditions (see, e.g., Leslie and Maguire,1978; Goikas, 1996; Milloy, 1979). Canada's Parliament accepted "the authority to legislate qua Indians pursuant to S. 91(24) of the Constitution Act, 1867," which, the Federal Court in Sawridge concluded, represented "a clear and plain intention to extinguish an aboriginal right or custom by which the identity and definition of Indians was established" (Sawridge Band v. Canada 1995). With an Indian assimilation program arguably still guiding policy makers, individuals 
living on reserves who did not become farmers or ranchers were expected to eventually abandon their outmoded lifestyle for urban advantage. In the 1950s, political infighting blossomed over precise responsibility for Indian populations, where federal policymakers portrayed reserve populations as Canada's authentic Indian communities under the Indian Act and thus solely entitled to federal programming dollars, much to the dismay of later urban Aboriginal peoples.22

Fourth, Canadian courts, in decisions such as Corbiere, now inform these and like issues. The court's determination in Corbiere, for example, that disenfranchisement by virtue of urban residency was discriminatory extended the First Nations franchise to band members living outside the community and with it a say in the community's daily governance. Viewed another way, the decision arguably prohibits a First Nation from avoiding responsibility for band members who have chosen urban residency.

\section{Does the UNDRIP Provide Clarity?}

The Corbiere decision that denying urban Aboriginal community members the right to vote in First Nation elections was discriminatory resonated with the UN Declaration's message that Indigenous individuals possess the right to "freely determine . . p political status." Article 6 asserts, "Every indigenous individual has the right to a nationality," and Article 3 buttresses these individual rights: "Indigenous peoples have the right of selfdetermination [to] freely determine their political status and freely pursue their economic, social and cultural development." Combined, these two articles appear to allow urban Aboriginal individuals to maintain their First Nations membership. Emergent tensions related to collective Indigenous rights versus newly identified individual Indigenous rights are evident upon further review of the Declaration's articles, as in Article 4: "Indigenous peoples, in exercising their right to self-determination, have the right to autonomy or self-government in matters relating to their internal and local affairs." Previously identified as an individual choice, membership is now also identified as a function of internal First Nations and urban Aboriginal governance.

Accepting that the individual Aboriginal right to determine political status is considered inviolable, how then do we measure the collective right of First Nations to determine membership against the individual right to determine political association? According to Article 9, "Indigenous peoples 
and individuals have the right to belong to an Indigenous community or nation, in accordance with the traditions and customs of the community or nation concerned. No discrimination of any kind may arise from the exercise of such a right." Evident in the wording of this article are two important issues. First, unlike Article 6, which speaks specifically to individual Indigenous rights informing personal membership choices, Article 9 identifies individual and collective Indigenous rights as equivalent. In a similar fashion to most political models informed by a mixture of individual and collective rights, the Declaration envisions providing political agency to Indigenous individuals who have been forced to work within the confines of individualistic, and often foreign, political models. When read together, the two articles promote an alternative, albeit conflicting, vision of membership and lead to the second issue: the UN considers traditional community membership selection methods and customs appropriate administrative mechanisms for determining contemporary First Nations membership. But what precisely does traditional mean in this context? These historic Indigenous governing processes were undermined by the newly confederated federal government as it sought to systematically alter traditional collective governing regimes by replacing them with foreign models emphasizing individual over collective rights. This challenged historic North American political systems that had embraced fluid citizenship models and ease of individual movement amongst communities that attained international political standing upon European crowns negotiating treaties or instituting diplomatic relationships with First Nations (Barsh, 1986; Henderson 2003, 2008b). In a perfect world, as Holder and Corntassel have suggested, "holistic indigenous world-views go well beyond liberal-individualist and corporatist explanations, which tend to frame the collective/individual rights debate in terms the individual's 'psychic health' as being contingent on group affiliation," which demands an "adequate philosophical treatment of collective rights" that circumvents "dichotomizing individualistic and collective interests" (Holder and Corntassel 2002, 149). The unfortunate reality is that these historic processes have been corrupted, and a fusion of historic Indigenous processes and Canadian policies and law has fostered new membership traditions. In sum, despite the Declaration's intent to see historic membership models informing contemporary membership selection processes, disentangling these myriad elements is literally impossible.

The aftermath of the 1985 changes to the Indian Act (Bill C-31) exemplifies this difficulty. In Alberta, the Sawridge First Nation in northern 
Alberta, the Tsuu T'ina First Nation nearby Calgary, and the Ermineskin First Nation of Hobbema $80 \mathrm{kms}$ south of Edmonton challenged the implementation of Bill C-31, claiming that it violated community practice and specifically the "woman follows man" custom that denied membership to women who married non-band members living outside the community. The Federal Court upheld the Bill C-31 amendments, undermining the First Nations' attempts to generate consensus regarding the meaning of citizenship after decades of federal intervention. The court also denied that any Aboriginal or treaty right existed that assigned First Nations control over membership under Section 35(1) of the Constitution Act, 1982. Moreover, had such rights existed, they had surely been extinguished by changes to the Constitution Act, 1982 (Sawridge Band v. Canada 1995). The Canadian government retains administrative oversight for First Nations membership. Arguably, utilizing tradition in this way will result in continued debates concerning who is a community member; and who is empowered to determine membership status, something the court ruled rests with the state.

The Declaration counters this conclusion by indicating, in Article 4, that "Indigenous peoples, in exercising their right to self-determination, have the right to autonomy or self-government in matters relating to their internal and local affairs." According to Henderson, notwithstanding the Sawridge decision, customary law promoting plurality of citizenship is a constitutionally protected process $(2003,418)$. This makes conceptualizing Aboriginal citizenship rather difficult, especially when we factor in urban Aboriginal desires to retain First Nations membership rights despite living outside the community. Historic Aboriginal citizenship paradigms are characterized by fluidity of citizenship and multiple community memberships, a process internalized by contemporary First Nations. The federal government--an outside agent--has openly challenged that citizenship paradigm. A second, outside agent, in the form of the UN, also informs the debate. For instance, by recognizing historic membership selection processes, the Declaration appears to freeze this tradition in an historical stasis, thus inhibiting the evolution of historic selection criteria. Even if the UN was to concede the fact that modern membership selection procedures are built on a traditional foundation, any membership codes that lead to the expulsion of Aboriginal individuals are deemed to violate individual Indigenous rights. The Declaration also states that First Nations have "the right to autonomy or self-government in matters relating to their internal and local affairs." So, on the one hand, should the community 
decide to exercise its self-determining authority to abolish a band member's citizenship status, they in turn have violated the Declaration's individual rights criteria. However, the individual citizenship choices protected by the Declaration have the potential to undermine a First Nation community's collective decision-making authority.

More specific to the urban Aboriginal discussion, by protecting the individual rights of those fleeing to the city seeking to improve their socioeconomic status, the UN has inadvertently pitted individual Indigenous rights against collective Indigenous rights, in the process amplifying the potential for First Nations/urban Aboriginal conflict. Individual right protections were implemented to ensure that individual choice to determine political status, for instance, was not influenced by outside agents. In such cases, a band council edict could result in lost membership status for those choosing to live outside their First Nations community, becoming an outside agent in the process and not what the Declaration's architects anticipated. The Declaration does, however, parallel the Supreme Court of Canada's conclusion that Aboriginality-residency is discriminatory, and seeks to enhance individual Indigenous rights. In doing so, one could interpret the Declaration as endorsing the Canadian courts' intervention in First Nations affairs to protect individual rights, a move that undermines the Declaration's spirit of Indigenous self-determination. Clearly we are at an impasse when determining how to respond when a First Nation alters its membership criteria to deny an individual choice of political membership. Or, more to the point, recognizing First Nation collective rights could potentially marginalize the individual Aboriginal choice of urban residency.

Acknowledging the state's underlying sovereignty demands also that we interpret the Declaration within the context of Canadian jurisprudence, adding analytical complexity. The Corbiere court, for instance, rightly concluded that reserve residents most often moved to the cities to improve their economic standing. Thus, in responding to social and economic circumstances beyond their control, urban Aboriginal peoples faced discrimination by virtue of their forced relocation. In the case of those individuals who choose an urban lifestyle over reserve residency and seek to retain their First Nation membership status, Section 6 of the Canadian Charter of Rights and Freedoms guarantees all Canadians the right to live in the community of their choice, essentially protecting each citizen's mobility rights. Subsection 2 reads, "Every citizen of Canada and every person who has the status of a permanent resident of Canada has the right: (a) to move 
to and take up residence in any province; and, (b) to pursue the gaining of a livelihood in any province." This section is based on the right to equal treatment, and entitles Aboriginal peoples to choose urban residency without penalty. Second, seeking to maintain their political affiliation with the First Nation as a registered voter, an individual right protected by the Supreme Court's Corbière decision, the individual is: (a) asserting her Article 6 rights to a nationality while (b) also freely determining her political status. The Declaration and domestic law appear to work in concert to protect individual Indigenous rights. Corbière prohibits a First Nation from renouncing responsibility for band members choosing an urban lifestyle, ensuring the individual urban Aboriginal right to freely determine political associations. Offering additional protection is the Charter of Rights and Freedoms (S. 15) guarantee indicating that "every individual is equal before and under the law and has the right to the equal protection and equal benefit of the law without discrimination and, in particular, without discrimination based on race, national or ethnic origin, colour, religion, sex, age or mental or physical disability."

By disallowing communities the opportunity to develop exclusive citizenship codes that may challenge individual claims to First Nations membership, the Declaration, Corbière, and the Charter of Rights and Freedoms combined appear to undermine the Declaration's Article 4, which indicates that Indigenous communities "have the right to autonomy or self-government in matters relating to their internal and local affairs." Misquadis (2002) subsequently debunked the popular notion (upheld on appeal) that urban Aboriginal residents are in some way less Aboriginal or "less worthy of recognition, and viewed as being disorganized and less accountable than other [read reserve] Aboriginal peoples" (Ardoch Algonquin First Nation v. Canada (Attorney General) 2003, pgh 126). The court thereby legally challenged the view that urban émigrés were no longer interested in their home communities' political development, potentially undermining contemporary First Nations assertions suggesting that cities are natural extensions of traditional lands. In one sense, the cities inform the construction of identities that are uniquely urban yet concomitantly informed by First Nations social and political norms (Andersen 2005; Wilson and Peters 2005). This has led to rising numbers of urban Aboriginal peoples demanding recognition of their political communities' distinctive rights (Simpson 2000). The distinctive socio-economic nature of urban Aboriginal communities means, however, that First Nations rarely devote 
resources to urban development projects, exposing yet another paradox: First Nation leaders will find it increasingly difficult to uphold claims to urban landscapes, especially if the communities in question refuse citizenship for urban members living in self-proclaimed traditional "urban" homelands.

\section{Conclusion}

The United Nations Declaration on the Rights of Indigenous Peoples is a complex document that its architects spent decades refining. It is expansive in interpretation and optimistic in scope, specifically in its implicit acknowledgement of urban Indigenous self-determination. Equally progressive is its attempt to call attention to both collective and individual Indigenous rights. As this paper has shown, despite its potential to expand the Indigenous self-determination dialogue, Canada's First Nation and urban Aboriginal leadership must become aware of the pitfalls associated with using the Declaration to improve localized governing authority. Using community membership as an example, asserting individual choice to establish community membership is an act of self-determination that also has the potential to challenge First Nations collective choices to exclude those individuals from membership due to their choice to live outside the community confines. At the same time, the latter decision to deny membership is in violation of the Declaration's individual rights guarantees. Add to this the conflicting domestic legal, political, and social perspectives concerning both the governing authority of First Nations and urban Aboriginal political authority, and it is evident that resolving issues related to governance and individual choice has been complicated to a degree where it could take years, if not decades, to reconcile the various perspectives. As I have argued in other places, conclusions of which are supported by the above analysis, based on a close reading of the Declaration informed by domestic law, policy, and social attitudes, it appears that individual and collective urban Aboriginal rights trump First Nations collective rights (Belanger 2010). However, additional studies are required prior to First Nation, Aboriginal, and Canadian political leaders venturing forward too quickly in their desires to implement and activate the Declaration's provisions to promote community development.

Despite the potential difficulties, the Declaration represents an important point of departure from the Canadian-Aboriginal selfdetermination dialogue. In addition to promoting Indigenous autonomy, 
the Declaration notably recognized the rights of Indigenous individuals. Most First Nation and Aboriginal leaders in Canada aggressively lobbied the federal government to endorse the Declaration, suggesting national support, but what most leaders have remained silent about is how precisely the Declaration will assist their respective communities. The purpose of this essay was to briefly examine how the Declaration, if implemented, will come to influence day-to-day First Nations and urban Aboriginal governmental operations. By focusing specifically on one salient issuethe tensions associated with the Declaration's acknowledged individual choice to determine political affiliation juxtaposed with its recognition of Indigenous collective self-determination-I have exposed the complexities inherent when attempting to reconcile the Declaration with First Nations and urban Aboriginal political aspirations, Canadian court decisions, federal Indian policies, and the protective mechanisms of the Canadian Charter of Rights and Freedoms. From this policy perspective, it is vital that we begin to comprehend not only how outside agents influence these operations, but also how the Declaration's progressive nature could lead to contentious moments of competing claims to legitimacy and self-determination. This essay is not meant to challenge the Declaration's importance, nor is it a critique of its architects' attempts at clarity. It is simply meant to provide an overview of some of the anticipated difficulties First Nations and urban Aboriginal leaders will face should they fail to probe the Declaration's exigencies and underlying messages.

\section{(Endnotes)}

1. Yale D. Belanger is associate professor, Native American Studies, University of Lethbridge. He would like to thank Peter Dinsdale, former executive director of the National Association of Friendship Centres (NAFC), and the NAFC for their earlier financial support of a project examining the forty-six UNDRIP articles, which influenced the above analysis (see Belanger 2010). Portions of this paper were also presented at "Reframing the Issues: Emerging Questions for Métis, non-status Indian and urban Aboriginal Policy Research", 79th Congress of the Humanities and Social Sciences, Concordia University (2 June 2010), Montreal, Quebec. The author would like to thank panel moderator Ellen Gabriel and 
several audience members for their questions and comments, which forced the author to both, reflect on his arguments and conclusions.

2. The term "Aboriginal people" indicates any one of the three legally defined culture groups that form what is known as Aboriginal peoples in Canada (Métis, Inuit, and Indian) and who self-identify as such. The term "First Nation" is used here to denote a reserve, community, or band. The term "Indian," as used in legislation or policy, will also appear in discussions concerning such legislation or policy. The term "Indigenous" here does not represent a legal category. Instead, it is used to describe the descendants of groups in a territory at the time when other groups of different cultures or ethnic origin arrived there, groups that have almost preserved intact the customs and traditions of their ancestors similar to those characterized as Indigenous, and those that have been placed under a state structure that incorporates national, social, and cultural characteristics distinct from their own.

3. The United States, Australia and New Zealand also refused to ratify the UNDRIP. The eleven abstentions were as follows: Azerbaijan, Bangladesh, Bhutan, Burundi, Colombia, Georgia, Kenya, Nigeria, the Russian Federation, Samoa, and Ukraine. Australia has since reversed its position and now endorses the Declaration. Colombia and Samoa have also reversed their positions and indicated their support for the Declaration.

4. These articles are as follows:

Article 19: States shall consult and cooperate in good faith with the indigenous peoples concerned through their own representative institutions in order to obtain their free, prior and informed consent before adopting and implementing legislative or administrative measures that may affect them.

Article 26(1): Indigenous peoples have the right to the lands, territories, and resources which they have traditionally owned, occupied or otherwise used or acquired; 26(2): Indigenous peoples have the right to own, use, develop and control the lands, territories and resources that they possess by reason of traditional ownership or other traditional occupation or use, as well as those which they have otherwise acquired; 26(3) States shall give legal recognition and protection to these lands, territories and 
resources. Such recognition shall be conducted with due respect to the customs, traditions and land tenure systems of the indigenous peoples concerned.

5. Interview with Victoria Tauli-Corpuz, chairperson of the Permanent Forum. (Sigurdarson 2009).

6. Canada (Attorney General) v. Misquadis [2003] FCA 370

7. Canada has a long and storied history of engaging in the same process. See Belanger and Newhouse (2004).

8. Quoted from Indian and Northern Affairs Canada, 2010, The Government of Canada's Approach to Implementation of the Inherent Rights and Negotiation of Self-Government, http://www.ainc-inac.gc.ca/al/ldc/ccl/ pubs/sg/sg-eng.asp\#PartI.

9. For an excellent discussion of the issues at hand, see the essays in Walkem and Bruce, (2003).

10. Article 1: Indigenous peoples have the right to the full enjoyment, as a collective or as individuals, of all human rights and fundamental freedoms as recognized in the Charter of the United Nations, the Universal Declaration of Human Rights and international human rights law.

11. Article 2: Indigenous peoples and individuals are free and equal to all other peoples and individuals and have the right to be free from any kind of discrimination, in the exercise of their rights, in particular that based on their indigenous origin or identity.

12. Article 3: Indigenous peoples have the right of self-determination. By virtue of that right they freely determine their political status and freely pursue their economic, social and cultural development.

13. Article 4: Indigenous peoples, in exercising their right to selfdetermination, have the right to autonomy or self-government in matters relating to their internal and local affairs, as well as ways and means for financing their autonomous functions.

14. Article 5: Indigenous peoples have the right to maintain and strengthen their distinct political, legal, economic, social and cultural institutions, while retaining their rights to participate fully, if they so choose, in the political, economic, social and cultural life of the State. 
15. Article 6: Every indigenous individual has the right to a nationality.

16. Article 9: Indigenous peoples and individuals have the right to belong to an indigenous community or nation, in accordance with the traditions and customs of the community or nation concerned. No discrimination of any kind may arise from the exercise of such a right.

17. Article 33 (1 and 2): (1) Indigenous peoples have the right to determine their own identity or membership in accordance with their customs and traditions. This does not impair the right of indigenous individuals to obtain citizenship of the States in which they live. (2) Indigenous peoples have the right to determine the structures and to select the membership of their institutions in accordance with their own procedures.

18. Article 35: Indigenous peoples have the right to determine the responsibilities of individuals to their communities.

19. For this general history, see Miller 2004.

20. For a general discussion of this topic, see Wuttunee 2004; Newhouse and Peters 2003; Ketilson 2004.

21. The consistently limited federal Indian Affairs allocations, combined with the devolution of funding for urban Aboriginal issues to various federal ministries, are evidence of this approach.

22. Take, national Aboriginal health care, as an example, which deteriorated well into the 1950s. At that time, citing spiralling costs, federal officials endeavoured to convince provincial premiers to accept responsibility for First Nations health while simultaneously scaling back health programming. Persistent provincial resistance was the norm until 1964 when, at the FederalProvincial Conference on Indian Affairs, federal officials re-introduced their proposed slow devolution of the Indian health care program and its associated costs to the provinces (see Canada 1964).

\section{References}

Anaya, James. 1996. Indigenous Peoples in International Law. New York: Oxford University Press. 
Andersen, Chris. 2005. "Residual Tensions of Empire: Contemporary Métis Communities and the Canadian Judicial Imagination." In Reconfiguring Aboriginal-State Relations: Canada: The State of the Federation, ed. M. Murphy, 295-325. Montreal and Kingston: McGill-Queen's University Press.

Ardoch Algonquin First Nation v. Canada (Attorney General), 2003, FCA 473.

Barsh, Russel Lawrence. 1986. "The Nature and Spirit of North American Political Systems." American Indian Quarterly 19 (3): 181-98.

- - . 1995. "The Aboriginal Issue in Canadian Foreign Policy, 19841994.” International Journal of Canadian Studies 12: 107-33.

- - - 1996. "Indigenous Peoples and the UN Commission on Human Rights: A Case of the Immovable Object and the Irresistible Force." Human Rights Quarterly 18: 782-813.

Belanger, Yale D. 2010. The United Nations Declaration on the Rights of Indigenous Peoples (UNDRIP) and Urban Aboriginal SelfDetermination in Canada. Ottawa: National Association of Friendship Centres.

Belanger, Yale D., Kevin Fitzmaurice, and David R. Newhouse. 2008. "Creating a Seat at the Table: A Retrospective Study of Aboriginal Programming at Canadian Heritage." Canadian Journal of Native Studies 28 (1): 33-70.

Belanger, Yale D. and David R. Newhouse. 2004. "Emerging from the Shadows: The Pursuit of Aboriginal Self-Government to Promote Aboriginal Well-Being." Canadian Journal of Native Studies 24 (1): 129-222.

- - - 2008. "Reconciling Solitudes: A Critical Analysis of the SelfGovernment Ideal." In Aboriginal Self-Government in Canada: Current Trends and Issues, 3rd ed., ed. Yale D. Belanger, 1-19. Saskatoon: Purich Publishing. 
Belanger, Yale D. and Ryan Walker. 2009. "Interest Convergence \& Co-production of Plans: An Examination of Winnipeg's 'Aboriginal Pathways'." Canadian Journal of Urban Research 18 (1): 118-39.

Biolsi, Thomas. 2005. "Imagined Geographies: Sovereignty, Indigenous Space, and American Indian Struggle." American Ethnologist 32 (2): 239-59.

Borrows, John. 2000. “'Landed' Citizenship: Narratives of Aboriginal Political Participation." In Citizenship in Diverse Societies, ed. Will Kymlicka and Wayne Norman, 326-44. Toronto: Oxford University Press.

Brant, Clare. 1990. "Native Ethics and Rules of Behaviour." Canadian Journal of Psychiatry 35: 534-39.

Bruyneel, Kevin. 2007. The Third Space of Sovereignty: The Postcolonial Politics of U.S.-Indigenous Relations. Minneapolis: University of Minnesota Press.

Cabo, Jose Martinez. 1987. Study of the Problem of Discrimination Against Indigenous Populations. Volume V: Conclusions, Proposals and Recommendations. New York: United Nations.

Canada. 1964. Federal-Provincial Conference on Indian Affairs: Report of Proceedings Ottawa: Indian Affairs Branch, Department of Citizenship and Immigration.

Canada. 2010. A Stronger Canada: A Stronger Economy: Now and for the Future Electronic serial in PDF format, p. 19. [online] http:// www.discours.gc.ca/grfx/docs/sft-ddt-2010_e.pdf.

Canada. Indian and Northern Affairs. 1995. The Government of Canada's Approach to Implementation of the Inherent Rights and Negotiation of Self-Government. http://www.ainc-inac.gc.ca/al/ldc/ccl/pubs/sg/ sg-eng.asp\#PartI. 
Canada (Attorney General) v. Esquega [2008] FCA 182

Canada (Attorney General) v. Misquadis [2002] FCA 370

Corbiere v. Canada (Minister of Indian and Northern Affairs), [1999] 2 S.C.R. 203.

Fiske, Jo-anne, Yale D. Belanger, and david Gregory. 2010. "Outsiders in Their Homeland: Discursive Construction of Aboriginal Women and Citizenship." American Indian Culture and Research Journal 34 (3): 71-92.

Francis, Daniel. 1992. The Imaginary Indian: The Image of the Indian In Canadian Culture. Vancouver: Arsenal Pulp Press.

Furniss, Elizabeth. 1999. The Burden of History: Colonialism and the Frontier Myth. Vancouver: UBC Press.

Garcia-Alix, Lola, and Robert K. Hitchcock. 2009. “A Report from the Field: The Declaration on the Rights of Indigenous Peoples Implementation and Implications." Genocide Studies and Prevention 4 (1): 99-109.

Goikas, John. 1996. "The Indian Act: Evolution, Overview, and Options for the Amendment and Transition." In For Seven Generations: An Information Legacy of the Royal Commission on Aboriginal Peoples. CD-ROM. Ottawa: Canada Communications Group.

Grammond, Sebastien. 2009. Identity Captured By Law: Membership in Canada's Indigenous Peoples and Linguistic Minorities. Montreal and Kingston: McGill-Queen's University Press.

Groves, Robert K. and Bradford W. Morse. 2004. "Constituting Aboriginal Collectivities: Avoiding New Peoples 'In Between'.” Saskatchewan Law Review 67 (1): 263-305.

Henderson, James [Sakej] Youngblood Henderson. 2003. "Sui Generis and Treaty Citizenship.” Citizenship Studies 6 (4): 415-40. 
- - - 2008a.Indigenous Diplomacy and the Rights of Peoples: Achieving UN Recognition. Saskatoon, SK: Purich.

- - . 2008b. "Treaty governance." In Aboriginal Self-Government in Canada: Current Trends and Issues. 3rd ed., ed. Yale D. Belanger, 20-38. Saskatoon, SK: Purich.

Henderson, James Youngblood. 2006. First Nations Jurisprudence and Aboriginal Rights: Defining the Just Society. Saskatoon: Native Law Centre.

Jamal, Mahmud. 2005. “The Misquadis Case.” In Legal Aspects of Aboriginal Business Development, ed. Joseph Eliot Magnet and Dwight A. Dorey, 123-36. Toronto: Butterworths.

Ketilson, Lou Hammond. 2004. "Aboriginal Co-operatives in Canada." Review of International Co-operation 97 (1): 38-47.

Ladner, Kiera and Michael Orsini. 2005. “The Persistence of Paradigm Paralysis: The First Nations Governance Act as the Continuation of Colonial Policy." In Canada: The State of the Federation 2003, ed. Michael Murphy, 185-206. Kingston, ON: Institute of Intergovernmental Relations.

Leslie, John and Ron Maguire. 1978. The Historical Development of the Indian Act. Ottawa: Treaties and Historical Research Centre, DIAND.

Little Bear, Leroy. 1996. "Relationship of Aboriginal People to the Land and the Aboriginal Perspective on Aboriginal Title." In For Seven Generations: An Information Legacy of the Royal Commission on Aboriginal Peoples. Ottawa: Canada Communications Group. CD-ROM. Cited in Royal Commission on Aboriginal Peoples, Treaty Making in the Spirit of Co-Existence: An Alternative to Extinguishment. Ottawa: Canada Communications Group, 1994. 
MacDonald, Noni and Amir Attaran. 2007. “Jordan's Principle, Government's Paralysis." Canadian Medical Association Journal 177 (4): 321.

Macklem, Patrick. 2001. Indigenous Difference and the Constitution of Canada. Toronto: University of Toronto Press.

McFarlane, Peter. 1993. Brotherhood to Nationhood: George Manuel and the Making of the Modern Indian Movement. Toronto: Between the Lines.

Miller, J.R.. 2004. Skyscrapers Hide the Heavens: A History of IndianWhite Relations in Canada. 3rd ed. Toronto: University of Toronto Press.

Milloy, John Sheridan. 1979. The Era of Civilization: British Policy for the Indians of Canada, 1830-1860.Ph D diss., Oxford University.

Newhouse, David R. 2003. “The Invisible Infrastructure: Urban Aboriginal Institutions and Organizations." In Not Strangers in These Parts: Urban Aboriginal Peoples, ed. David R. Newhouse and Evelyn Peters, 243-54. Ottawa: Policy Research Initiative.

Niezen, Ronald. 2003. The Origins of Indigenism: Human Rights and the Politics of Identity. Berkeley and Los Angeles: University of California Press.

Peach, Ian. 2004. The Charter of Rights and Off-Reserve First Nations People: A Way to Fill the Public Policy Vacuum. Saskatchewan Institute of Public Policy Public Policy Paper No. 24. Regina: Saskatchewan Institute of Public Policy.

Peters, Evelyn. 1996. “'Urban’ and ‘Aboriginal': An Impossible Contradiction?" In City Lives and City Forms: Critical Research and Canadian Urbanism, ed. Jon Caulfield and Linda Peake, 47-62. Toronto: University of Toronto Press. 
Reynolds, James I. 2005. A Breach of Duty: Fiduciary Obligations and Aboriginal Peoples. Saskatoon: Purich Publishing.

Sawridge Band v. Canada [1995] 4 C.N.L.R. 121 (F.C.T.D.).

Sigurdarson, Broddi. 2009. "Now that the UNDRIP has been adopted, what are the next steps for IPs at the international level: Interview with Victoria Tauli-Corpuz, Chairperson of the Permanent Forum." http://www.indigenousportal.com/Self-Determination/Now-thatthe-UNDRIP-has-been-adopted-what-are-the-next-steps-for-IPs-atthe-international-level.html.

Simpson, Audra. 2000. "Paths Toward a Mohawk Nation: Narratives of Citizenship and Nationhood in Kahnawake." In Political Theory and the Rights of Indigenous Peoples, ed. D. Ivison, P. Patton, and W. Sanders, 113-36. Toronto: Cambridge University Press.

Slattery, Brian. 2007. "A Taxonomy of Aboriginal Rights." In Let Right Be Done: Aboriginal Title, the Calder Case and the Future of Indigenous Rights, ed. Hamar Foster, Heather Raven, and Jeremy Webber, 111-28. Vancouver: UBC Press.

Starke, J.G. 1989. An Introduction to International Law. 10th ed. London: Butterworths.

Strahl, Chuck. 2007. “A Document Canada Couldn't Sign: The UN's Declaration of Aboriginals Is Incompatible with Our Constitution." The National Post, 14 September, A-16.

Taiaike, Alfred and Jeff Corntassel. 2005. "Being Indigenous: Resurgences Against Contemporary Colonialism." Government and Opposition 40 (4): 597-614.

Tomiak, Julie. 2009. Urban Aboriginal Self-Governance in Ottawa, Winnipeg and Vancouver: Trends, Problems and Perspectives. Ottawa: Institute on Governance. 
Treaty 7 Elders and Tribal Council with Walter Hildebrant, Sarah Carter, and Dorothy First Rider. 1996. The True Spirit and Intent of Treaty 7. Kingston and Montreal: McGill-Queen's University Press.

Tully, James. 2000. “The Struggles of Indigenous Peoples for and of Freedom." In Political Theory and the Rights of Indigenous Peoples, ed. Duncan Ivison, Paul Patton, and Will Sanders. Cambridge: Cambridge University Press.

United Nations. 2007. United Nations Declaration on the Rights of Indigenous Peoples. New York: United Nations.

United Nations Permanent Forum on Indigenous Issues. 2007. “The United Nations Declaration on the Rights of Indigenous Peoples: Adopted by the General Assembly 13 September 2007.” http://www.un.org/ esa/socdev/unpfii/en/declaration.html.

Walkem, Ardith and Halie Bruce. 2003. Box of Treasures or Empty Box? Twenty Years of Section 35. Penticton, BC: Theytus Books.

Wilmer, Franke. 1993. The Indigenous Voice in World Politics Since Time Immemorial Thousand Oaks, CA: Sage Press.

Wilson, Kathi and Evelyn Peters. 2005. "'You can make a place for it': Remapping Urban First Nations Spaces of Identity." Society and Space 23: 395-413.

Wuttunee, Wanda. 2004. Living Rhythms: Lessons in Aboriginal Economic Resilience and Vision. Kingston and Montreal: McGill-Queen's University Press. 